\title{
Geographies of internationalism: radical development and critical geopolitics from the Northeast of Brazil
}

Federico Ferretti

federico.ferretti@ucd.ie

\begin{abstract}
This paper addresses the international networks of three Brazilian geographers who were exiled and persecuted after the establishment of a military dictatorship in Brazil in 1964 - Josué de Castro (1908-1973), Milton Santos (1926-2001) and Manuel Correia de Andrade (1922-2007) - whose works had an impact in the international field of critical scholarship in geography and development studies, which remains underplayed in present-day scholarship. Addressing for the first time their unpublished correspondence, whose inventory is ongoing in Brazilian archives, I reconstruct their international work, especially focusing on its constraints, to engage with recent debates on the geographies of internationalism and on international agencies problematizing the concepts of 'international geographies' and 'internationality' of scientific life. My main argument is that the study of informal networks of scientific sociability allows for an understanding of the constraints that institutions and states pose to the internationalization of knowledge, not only through political repression but also through the establishment of 'national schools'. On the other hand, these sources suggest that the exile can play a creative role in stimulating exchanges of knowledge, a concept, on which further research is needed in political geography.
\end{abstract}

Keywords: geographies of internationalism, geographies of exile, radical geographies, circulation of knowledge, critical geopolitics

This paper addresses the international networking of three Brazilian geographers who were exiled or persecuted at different levels after the 1964 military coup: Josué de Castro (19081973), Milton Santos (1926-2001), and Manuel Correia de Andrade (1922-2007). Santos, de Castro and de Andrade were all from the Northeast (Santos from Bahia, de Castro and de Andrade from Pernambuco), a Brazilian region characterized by a strong Afro-Brazilian presence and levels of poverty traditionally higher than the national average. They were part

'Geographies of internationalism: radical development and critical geopolitics from the Northeast of Brazil', Political Geography, 63, 2018 10-19, https://www.sciencedirect.com/science/article/pii/Sog62629817302597 
of international, cosmopolitan and multilingual scholarly and activist networks on geography and development, where they interacted with scholars from the 'Global North' and exerted an important influence in these radical circuits, especially in the 1960s and 1970s. Recent scholarship on Milton Santos, the most famous of the three (Ferretti and Viotto, 2017; Melgaço, 2017), shows how their works are worthy of reconsideration.

Drawing upon recent scholarship in the geographies of internationalism, I analyse the international networks of these geographers through a systematic survey of their unpublished correspondences that have survived in the archives of the Instituto de Estudos Brasileiros (IEB) in São Paulo, an indispensable tool for retracing their international connections, especially with European and North American scholars. This paper confirms and extends the claims of Santos's scholarship mentioned above on the early role that the 'Global South' played in 'theorizing back' (Slater, 1993), showing how Southern geographers were not dependent in theory but also exerted an influence on 'Northern' colleagues. My main argument is that this case shows how internationalism and transnationalism are rooted in activism and hindered by states, academies and 'national (or nationalistic) schools'. When these institutions fostered internationalization, it was often done indirectly by imposing exile and constraints on dissidents: thus, I also argue that the scholars' exile played a creative role in bolstering international circuits and multilingualism, as shown by works on other non-institutional scholarly circuits such as the anarchist geographers (Ferretti, 2011) or the Zimbabwean anticolonialists in London in the 1960s (McGregor, 2017). The potential of diaspora practices was already suggested by studies on literature (Said, 2000), on Latin American history (Sznejder and Roniger, 2007) and on Black internationalism, arguing that the diaspora intellectual 'can lay claim to a discourse of universality, and can gain purchase on the institutionalization of universality represented by international civil society' (Edwards, 2003, p. 116). This means that internationalism can be rooted in voluntarist, activists (and often radical or subversive) practices rather than in institutional arrangements.

In the last few years, historical and political geographies of internationalism have increasingly examined the time, spaces and places of the complex concept of 'the international' (Legg, 2014). Jake Hodder, Steve Legg and Mike Heffernan called for a reconceptualization of the

'Geographies of internationalism: radical development and critical geopolitics from the Northeast of Brazil', Political Geography, 63, 2018 10-19, https://www.sciencedirect.com/science/article/pii/Sog62629817302597 
idea of internationalism and transnationalism in geography, considering this to be an important task for political geography to undertake regarding the present global challenges, although 'Geography's puzzling silence in this regard suggests that the discipline is still too narrowly constrained by national contexts and frameworks' (Hodder, Legg and Heffernan, 2015, p. 2). These authors also hypothesize that the globalizing processes of the last decades have paradoxically hindered the processes of the internationalization of geography that have been ongoing since the eighteenth and nineteenth century in heterogeneous forms (Jöns, Meusburger and Heffernan 2017), by 'accelerating the discipline's concentration among isolated spokenlanguage blocks and, this has meant in practice, a globalized form of English' (Hodder, Legg and Heffernan, 2015, p. 3). The authors argue that this does not necessarily correspond to a drive for internationalization. The case study I address, shows that multilingualism and transcultural commitment are fundamental tools for internationalist and transnational approaches.

Therefore, this paper will contribute to this call for 'bringing together historical and political geographies of internationalism' (Hodder, Legg and Heffernan, 2015, p. 3) and address questions such as: how does 'the international relate to the imperial, the colonial, or the global manifestation of US nationalism? ... How can it be comprehended through regional and potentially radical internationalisms such as the Black Atlantic or the Black Pacific? ... What political or cultural components would an international community consist of?' (Hodder, Legg and Heffernan, 2015, p. 3). If this case can only provide provisional answers for these complex questions, two points stand out in the international networks I analyse: first, the importance of a political, humanitarian and ethical commitment to find global solutions for global problems, a task in which the exiled Brazilian geographers were inspired by the traditions of both Marxism and Anarchism. The second point is a confirmation of the idea that 'there must be some interconnection between internationalism and interdisciplinarity' (Hodder, Legg and Heffernan, 2015, p. 4); this is clearly shown by the international trajectories of De Castro, De Andrade and Santos, who mobilized geography connected to other disciplines, including medicine, planning, history, anthropology and development studies.

'Geographies of internationalism: radical development and critical geopolitics from the Northeast of Brazil', Political Geography, 63, 2018 10-19, https://www.sciencedirect.com/science/article/pii/Sog62629817302597 
Moreover, I assume that 'still too little work has been done on ... the role that scholars and intellectuals played in internationalist thought and practice' (Hodder, Legg and Heffernan, 2015, p. 5). Most recent scholarship has focused either on diplomatic international cooperation or international geographical congresses. As Hodder has correctly stated, 'internationalism and the international conference are inexorably entwined' (Hodder, 2015 p. 40). Recent works also focused on conferences and summits as places for hospitality and international cooperation, including development and decolonial networks (Craggs, 2014; Craggs and Mahony, 2014). Less attention has been given to informal and extra-institutional networks beyond 'summitry or state-accredited spaces of 'high diplomacy' (Hodder, 2015, p. 41). This paper assumes this problem exists in both conceptual and methodological plans. Regarding internationalism, I draw upon works considering non-statist geographies (Ince and Barrera de la Torre, 2016; Springer, 2016) and activist transnational solidarity networks (Featherstone, 2012) as a possibility for analysing the geographical features of political and scientific movements beyond institutional frames. In the case of international organizations, their contradictions and role as imperial devices have been highlighted, among others, by Legg in his studies on the League of Nations (Legg, 2009, 2014).

From a methodological standpoint, I provide an alternative view on internationalism beyond institutional frames of reference by studying both formal and informal networks of sociability. To do so, I draw upon the insights provided by research following scientific networks and distant connection (Latour, 1987) while using some methodological innovations as far as I apply my analysis to multilingual, transnational and cosmopolitan networks, which were minimally institutional or formalized. In addition, it is necessary to consider the concept of sociability as addressed by French historian Maurice Agulhon (1966) to follow personal and informal relations between these exiles and their international correspondents, considering the importance of biography for geography (Keighren et al., 2017; Withers 2007) and localizations and circulations of knowledge (Secord, 2004). This fits my specific conceptual goals; additionally, the Brazilian archives that I explore confirm that in these correspondences and unpublished materials, one finds elements to assess the weight, influence and dissemination range of these scholars' ideas that one cannot find through a work limited to their published texts.

'Geographies of internationalism: radical development and critical geopolitics from the Northeast of Brazil', Political Geography, 63, 2018 10-19, https://www.sciencedirect.com/science/article/pii/Sog62629817302597 
Regarding the places of internationalism, French scholarship has considered the histoire croisée (crossed history) as a conceptual tool to overcome a simple comparative approach between 'national schools' (Werner and Zimmermann, 2004), questioning the idea of unilateral cultural influence to address the material contacts among the actors of the circulation of knowledge (Espagne, 2013). Works by Marie-Claire Robic on the international geographical congresses have shown that scholarly life is not 'naturally' international: indeed, it is a complex matter that requires consideration of 'material spatialities, made of places and encounters, of networks where ideas and people circulate, which occurs at different scales of scientific life' (Robic, 2013, p. 39). This matches Hodder's argument that 'internationalism, and "the international", was not a given category or scale, but a way of encasing different conceptions of the world which were tied to the places in which it was debated and sustained' (Hodder, 2015 , p. 40). Thus, a first answer to the question of placing internationalism is that internationalism has no simple place, and its networks need to be considered at different scales and temporalities, with a special consideration for places and contexts.

The arguments I address in this paper also extend recent scholarship on US policies in philanthropy and international development. David Nally and Stephen Taylor have highlighted the paternalistic role philanthropy played in the 'long green revolution' and especially the programmes of the Foundation Rockefeller in Latin America such as 'Strategy for the Conquest of Hunger'. The authors argue that these programmes 'reflected Cold War logics ... Satisfying the immediate nutritional needs of hungry peasants was one method of silencing the pedlars of revolution, but the provision of handouts was never a sustainable strategy in the long-term.... rural development became a geopolitical imperative: to stave off a "Red Revolution" it was necessary to bring about a lasting "Green Revolution"” (Nally and Taylor, 2015, p. 57). This international paternalism 'from the North' was one of the targets of De Castro, De Andrade and Santos, who first countered neo-colonialism (Mançano Fernandes and Porto-Gonçalves, 2007; Ross, 2011). Works by Mona Domosh have likewise shown how 'some of the practices that characterize American international development have their roots in the early 20th century, particularly in the American South' (Domosh, 2015, p. 17). Imperial international politics were performed when 'corporate leaders imagined the expansion of their markets beyond U.S.

'Geographies of internationalism: radical development and critical geopolitics from the Northeast of Brazil', Political Geography, 63, 2018 10-19, https://www.sciencedirect.com/science/article/pii/Sog62629817302597 
borders as an extension of the expansion within those borders, with the transformative potential of their products ... turning 'primitive' peoples into 'modern' ones remaining constant and made to appear inevitable from the regional to the national to the international scale' (Domosh, 2015, p. 27). The experiences of the Brazilian geographers persecuted by the military dictatorship in 1964 provide radically different examples of internationalism and transnationalism.

In the first part of my paper, I address the trajectory of the oldest of the three geographers, Josué de Castro, who was considered a master by the other two, and make an initial attempt to reconstruct his role on both sides of the French-Brazilian intellectual exchange. In the second part, I analyse the role of de Andrade and what I call 'the international hub' of Recife by addressing for the first time his unpublished correspondence, whose inventory is ongoing, and by insisting on the institutional constraints to his international activities. In the third part, I address Santos's links to European, North and South American scholars from the specific standpoints of the hindrances that this international work encountered.

\section{Reading French geographers in Recife and pioneering critical geopolitics}

Born in Recife, the capital of Pernambuco, de Castro was first trained as a medical doctor, but he soon became interested in geography and the wider problems of hunger and poverty (De Andrade et al., 2003; Teles de Carvalho, 2009). The interdisciplinary range of his scholarly interests is witnessed by the correspondence he had in the 1930s with modernist poet Mario de Andrade (1893-1945), where de Castro discussed different projects, including his idea of going to Paris in 1937 to attend a congress of ethnographers. ${ }^{1}$ It is worth noting that in Brazil, modernism, tropicality and indigenous inheritance were not contradictory but concurred in attempts to create a national imagination by mixing modernity myths and indigenous traditions (Stepan, 2000). Strongly committed to social improvement and especially to the realization of agrarian reform (which remains unfinished business in Brazil), de Castro was a professor of geography at the Federal University of Rio de Janeiro, a deputy at the Federal Assembly from 1954, president of the Food and Agriculture Organisation (FAO) and Brazilian ambassador for

\footnotetext{
${ }^{1}$ São Paulo, Instituto de Estudos Brasileiros (hereafter IEB) MA-C-CPL1908, 7 April 1937, de Castro to de Moraes Andrade. All quotes from sources in Portuguese, Spanish and French have been translated by the author.
}

'Geographies of internationalism: radical development and critical geopolitics from the Northeast of Brazil', Political Geography, 63, 2018 10-19, https://www.sciencedirect.com/science/article/pii/Sog62629817302597 
the United Nations in Geneva. In 1964, the military council who took the power declared the forfeiture of his civil rights, ${ }^{2}$ compelling him to seek refuge in France, where he died in $1973 .{ }^{3}$ In the 1930s, de Castro was also one of the first Brazilian authors who quoted French geographers, such as Reclus and Vidal de la Blache, to apply their ideas to the social problems of Brazil. This was especially the case with Reclus, whom de Castro quotes as the unique European scientist of that time who did not avoid addressing serious famines that had affected countries such as India (De Castro, 1946 and 1952) and which are known today as 'Victorian Holocausts' (Davis, 2001).

A scholar whom Santos deemed one of his masters, de Castro remains a little-studied figure even in Brazil. For a long time, he was not considered a geographer, despite the fact that he held the Chair of Geography at the University of Rio de Janeiro from 1947 (Leite Linhares, 2007, p. 22). Santos was one of the first authors committed to dissipating this misunderstanding, which also attests to his acquaintance with de Castro. Their correspondence shows that the two men had already collaborated in the 1950s when Santos was a young scholar at the University of Bahia. In 1954, after congratulating de Castro for his election to the Federal Parliament, Santos invited him to give conference talks in Salvador and signed off as de Castro's 'friend, disciple and admirer' ${ }^{4}$. De Castro responded, accepting the invitation and congratulating Santos for his 'substantial contributions to the study of modern geography'. What is especially significant is that de Castro showed special interest in 'the works of the Bahia section of the Brazilian Institute of Geopolitics', what shows that the word 'geopolitics' was used by Brazilian radicals as early as the 1950s. ${ }^{5}$ This also shows a regional exchange among scholars from the Brazilian Northeast.

Almost thirty years later, by which time de Castro had died and had almost been forgotten, Santos proposed his name to sociologist Florestan Fernandes for a monograph in a series on Brazilian social scientists that Fernandes was editing. 'I thought of de Castro. When he was alive, many colleagues did not consider him a geographer. This mistake must now be corrected

\footnotetext{
${ }^{2}$ Recife, Fundação Joaquim Nabuco, Coordenação-Geral de Estudos da História Brasileira Rodrigo Melo Franco de Andrade (hereafter CEHIBRA), Acervo Josué de Castro, Folder 28, Cassação de Mandatos, 1964.

${ }^{3}$ CEHIBRA, Acervo Josué de Castro, Folder 554, Projeto de Biografia.

${ }^{4}$ IEB, MS-R554-001, Santos to de Castro, 16 October 1954

${ }^{5}$ IEB, MS-R554-001, de Castro to Santos, 28 December 1954.
}

'Geographies of internationalism: radical development and critical geopolitics from the Northeast of Brazil', Political Geography, 63, 2018 10-19, https://www.sciencedirect.com/science/article/pii/Sog62629817302597 
for our benefit' ${ }^{6}$ Fernandes's answer is emblematic: the editor considered this an original idea because de Castro "was not deemed a sacred cow. I remember that he also encountered some underestimation among sociologists and anthropologists'. ${ }^{7}$ Work in Brazil is reviving de Castro as a fundamental author who countered 'economists and reductionist views' (Mançano Fernandes and Porto-Gonçalves, 2007, p. 12) in geography, denouncing 'hunger and undernutrition as the social evils due to underdevelopment and colonialism' (Leite Linhares, 2007, p. 23). De Castro's geography is also considered an example of scholarship engaged against 'the abusive continuance of a system which offends human dignity by keeping all the powers in the hands of few privileged people' (De Castro, in Mançano Fernandes and PortoGonçalves 2007, p. 45), and his figure as that of 'a fighting geographer, one who played a role close to that played in France by Elisée Reclus' (De Andrade, 2006, p. 88). As Santos synthetized, 'being prickly was not a problem for de Castro' (Soares, 2003, p. 10).

To assess de Castro's influence in international debates, it is worth considering the process that led to the definition of geopolitics as a progressive discipline. As historians of geography know well, in the aftermath of the Second World War, this term was abandoned by most geographers for its strong identification with German geopolitics that were close to Nazism (Mamadouh, 1999). Only in the 1970s and 1980s did critical and left-wing geopolitics first become active, mainly due to geographers such as John Agnew, Gearoid Ó Tuathail and others in the Anglophone world. In France, Yves Lacoste and the group Hérodote (1976) were responsible for the rehabilitation of this definition (Hepple, 2000). Nevertheless, de Castro used this word as early as the 1940s in a different way than right-wing geographers such as Carl Haushofer or Rudolf Kjéllen, in a book soon translated into French with a preface of famous "Vidalian" geographer Max Sorre (De Castro, 1952). Moreover, works such as those by De Castro, together with that of Santos, clearly had an impact on the discovery of the problems of hunger and 'underdevelopment' by French geographers. Josué de Castro is often quoted in early works on this subject by Yves Lacoste (1962), who was acquainted with him. According to de Andrade, de Castro collaborated with Pierre Monbeig for the foundation of the Institute of Advanced Studies on Latin America (De Andrade, 1997, p. 7), and he also played a role in the

\footnotetext{
${ }^{6}$ IEB, MS-RS83-040, Santos to Fernandes, 21 May 1983.

${ }^{7}$ IEB, MS-RS83-042, Fernandes to Santos, 2 June 1983.
}

'Geographies of internationalism: radical development and critical geopolitics from the Northeast of Brazil', Political Geography, 63, 2018 10-19, https://www.sciencedirect.com/science/article/pii/Sog62629817302597 
alternative university founded in Vincennes in 1968, where he worked with scholars such as Lacoste, Michel Foucault and Gilles Deleuze (Bué, 1996). Thus, further work is needed on de Castro's ideas and on his (neglected) roles in shaping international scholarly and political debates in addition to his activism against world hunger (Carvalheira do Nascimento, 2009).

De Castro was a pivotal figure for Brazilian and international circuits of critical geographies in the 1960s and 1970s. While work on his personal archives in Recife is only at the beginning, it is possible to conclude that de Castro's work inspired the Santos and de Andrade's scholarly generation. De Andrade argued for the importance of de Castro's' early critiques of mainstream ideas on development. '[He argued that] underdevelopment is a product or sub-product of development, an inevitable derivation of the economic colonial or neo-colonial exploitation, which is still ongoing in different regions of the planet' (De Andrade, 2003, p. 74). Another element that characterized both Brazilian and international critical scholarship was antiMalthusianism, a topic still discussed in development debates (Peet and Hartwick, 2015). According to de Castro's writings reprinted by de Andrade, 'the falsity of the argument that pretends that it is impossible to be rid of hunger, following the old Malthusian concept that the world has to end with a famine, because the progression of population occurs faster than the growth of food production. This is completely false. The world has enough resources to nourish a population far larger than the present one' (De Castro, in de Andrade, 2003, p. 120). These arguments still resonate in present-day debates, against which Malthusianism and global resources are debated, and geographies of hunger remain an urgent matter as part of 'food security' and its criticisms (Nally, 2016). Finally, the internationalism of de Castro's approaches is witnessed by his statements at the international organizations' meetings he attended, such as: 'It is impossible to exit this situation without a larger union of all the people of the world to act against imperialism and colonialism. It will be only at that moment that we can be sure to win our war against war and gain peace' (De Castro, in de Andrade, 2003, p. $123)$.

\section{Manuel Correia De Andrade and the 'Recife hub': dealing with a dictatorship}

One of de Castro's followers who contributed to his partial rediscovery from the 1990s was Manuel Correia de Andrade. Born in 1922, de Andrade was teacher of geography and history

'Geographies of internationalism: radical development and critical geopolitics from the Northeast of Brazil', Political Geography, 63, 2018 10-19, https://www.sciencedirect.com/science/article/pii/Sog62629817302597 
in different Pernambuco colleges and later became involved in local development agencies such as the SUDENE (Superintendência do Desenvolvimento do Nordeste) ${ }^{8}$ and cultural institutions such as the Foundation Joaquim Nabuco. Today, his name is associated, among others, with the 'critical turn' Brazilian geography took after the 1978 Fortaleza congress (Borzacchiello, 2016). De Andrade was not 'technically' exiled but was persecuted by the regime as well. After his 1964-65 stay in France, de Andrade could return to Recife and keep his university chair, although his archives bear witness to the harassments he suffered in the 1960s and 1970s, especially through the attempts of local authorities to hinder his international mobility.

In an autobiographical statement he produced in 1973 for administrative reasons, de Andrade discreetly mentioned his former troubles with political repression. This document also reveals the attention the authorities paid to his international mobility. 'I was already imprisoned twice but was not charged or put on trial. It was in August 1944, after taking part in an electoral demonstration against the Estado Novo and supporting the possible candidature of Brigadier Eduardo Gomes for the Presidency of the Republic, and in April 1964, after signing a manifesto of solidarity with the government a few days before it was deposed. These events occurred in Recife, the State of Pernambuco. Evidently, I was never sentenced'9. Such episodes reveal the militant background of de Andrade in the struggle against the two main dictatorships of twentieth century Brazil, the Estado Novo (1937-1945) led by Getúlio Vargas and the 1964 military coup that deposed the last of the democratic governments elected since the 1950s. The military dictatorship would remain until 1985.

This document also shows how de Andrade was asked to account for all his travels abroad from 1958. His stay in France in 1964-65 is described as follows: 'I sojourned in France from November 1964 to June 1965 as a bursary of the French government, with the permission of the Federal and State governments (Brazil and Pernambuco), to attend a postgraduate programme. In that period, I enjoyed tourist excursions in Portugal, Netherlands, Luxembourg,

\footnotetext{
${ }^{8}$ This was a regional agency that was founded in 1959 to foster social economy in the Brazilian Northeast and then marginalized during the dictatorship under the pretext of corruption, but in fact due to the critical ideas of its members and inspirers, including de Castro. See CEHIBRA, Acervo Josué de Castro, Folder 506, SUDENE.

${ }^{9}$ IEB- Acervo Manuel Correia de Andrade (hereafter MCA), Caixa 39, De Andrade's CV, 15 May 1973.
}

'Geographies of internationalism: radical development and critical geopolitics from the Northeast of Brazil', Political Geography, 63, 2018 10-19, https://www.sciencedirect.com/science/article/pii/Sog62629817302597 
Germany, Switzerland, Italy and Greece. I went to Israel by invitation of the Tel Aviv faculty of social science to attend an international conference on cooperatives and rural development.' ${ }^{10}$ The following professional sojourns listed in the document were 'Peru in 1967 to attend a symposium on the utilization of coastal deserts promoted by the International Geographical Union with the support of UNESCO, and then Chile to give a conference talk at the Catholic University in Santiago. The United States in 1968 to give conference talks at the University of California (Riverside and Los Angeles) and Columbia (New York) with a stop in Mexico City ... Monaco, France and Spain in 1969, by invitation of the European Association for World Universities to attend the Symposium on underdevelopment organized in Monte Carlo.' 11

As in the case of de Castro, French geography was the first international reference for de Andrade. His rich list of French correspondents was virtually the same as that of Milton Santos. Among those whom Santos called 'our [common] friends' in a 1966 letter sent from Toulouse, ${ }^{12}$ one sees the names of Jean Roche (1917-2006), Louis Papy (1903-1990), Guy Lasserre (1920-2001), Michel Rochefort (1927-2015), Bernard Kayser (1926-2001), Pierre Monbeig (1907-1977), Jacqueline Beaujeu-Garnier (1917-2005), Jacques Bethemont (19282017), Michel Philipponneau (1921-2008), Pierre George (1909-2006), Olivier Dollfus (19312005), Jean Dresch (1905-1994) ${ }^{13}$. Unlike de Castro, who was forced into exile, and Santos, who chose to expatriate to escape a situation that he could not tolerate (Contel, 2014), de Andrade chose to remain in Pernambuco, where he enjoyed a more comfortable life than his exiled fellows but experienced limitations in his freedom of movement. I would argue that his first strategy to cope with this was his willingness to transform Recife and the Northeast into an international hub for critical geographers and development scholars. After his French sojourn in 1964-65, he received Lasserre (University of Bordeaux), who proceeded from São

\footnotetext{
${ }^{10}$ IEB-MCA, Caixa 39, De Andrade's CV, 15 May 1973.

${ }^{11}$ IEB-MCA, Caixa 39, De Andrade's CV, 15 May 1973.

12 IEB-MCA, Caixa 35, Santos to de Andrade, 4 May 1966.

13 All the members of this list were French geographers or development scholars, politically left-wing and interested in Latin America at different levels. Some of their biographies have been included in the collection Geographers, Biobibliographical Studies. The others' biographies will be included accordingly in the next few years in the context of a collaboration between the IGU Commission History of Geography and the Paris research cluster EHGO (Epistémologie et Histoire de la Géographie).
}

'Geographies of internationalism: radical development and critical geopolitics from the Northeast of Brazil', Political Geography, 63, 2018 10-19, https://www.sciencedirect.com/science/article/pii/Sog62629817302597 
Paulo in November 1965 to 'visit the Northeast.' ${ }^{14}$ In 1967, De Andrade included 'the presence of professor Jean Roche ... from the University of Toulouse' ${ }^{15}$. In 1968, Kayser, likewise from Toulouse, came to Recife after a trip that included the United States, Argentina, Paraguay, Rio de Janeiro and Salvador. ${ }^{16}$ The invited speaker for 1969, Philipponneau (University of Rennes), proposed the following as topics for his conferences: 'The role of the [IGU] Commission for Applied Geography; Applied geography in France; Applied geography and regional planning in Brittany; Regional planning in Turkey' ${ }^{17}$. The correspondence between these scholars shows the importance of their sociability networks, especially the friendship between de Andrade and the French geographers mentioned above, because these 'pilgrimages' to see the Northeast sometimes appear to be 'development tourism' and are not always linked to identifiable scientific output. Nevertheless, this reveals the importance of the Pernambuco region for Northern development scholars, which was also due to the widespread acclaim of de Castro's writings. This is also the case with internationalism and hospitality (Craggs 2014) as an instrument for maintaining academic freedom in difficult situations such as that of de Andrade.

Among the constraints of internationalization, one can include the difficulty in finding literature on development, the Third World and decolonization in Brazil, where the press was all but free in the dictatorship's years. The voluminous correspondence de Andrade maintained with a Rio de Janeiro book importer called French Bookshop (Livraria Francesa) reveals that he had to order all the international literature on Latin America he needed from France, such as the Che Guevara Bolivia Diary, ${ }^{18}$ essays on Latin America by French radical philosopher Régis Debray, essays on African decolonization by Jomo Kenyatta and other decolonizers, and even the books of Milton Santos published in French. ${ }^{19}$ These letters reveal the constraints but also the spectacular amount of de Andrade's reading and intellectual interests, which were not limited to geography and development but comprised a wide range of classic works on Marxism, socialism and anarchism (including Kropotkin) ${ }^{20}$. Throughout the 1960s and 1970s, de Andrade's orders from French publishers averaged hundreds of books per year. Therefore,

\footnotetext{
${ }^{14}$ IEB-MCA, Caixa 35, Lasserre to de Andrade 4 November 1965.

${ }^{15}$ IEB-MCA, Caixa 34, De Andrade to Costa Carvalho, 16 May 1969.

${ }^{16}$ IEB-MCA, Caixa 34, Kayser to de Andrade, 1 September 1968.

${ }^{17}$ IEB-MCA, Caixa 34, Philipponneau to de Andrade, 13 June 1969.

${ }^{18}$ IEB-MCA, Caixa 34 Livraria Francesa to de Andrade, 1 November 1968.

${ }^{19}$ IEB-MCA, Caixa 34, Livraria Francesa to de Andrade, 12 March 1968.

${ }^{20}$ IEB-MCA, Caixa 40, Livraria Francesa to de Andrade, 26 July 1977.
}

'Geographies of internationalism: radical development and critical geopolitics from the Northeast of Brazil', Political Geography, 63, 2018 10-19, https://www.sciencedirect.com/science/article/pii/Sog62629817302597 
it is possible to consider Recife not only as a hub but also an important centre of calculation (Latour, 1987) for critical development geographies in the harshest years of the Brazilian military dictatorship, which was accordingly not interested in censoring material in foreign languages.

Nevertheless, some correspondences appear to suggest that Correia, at the end of the 1960s, was seeking a definitive way out of Brazil. Some of these exchanges concerned the development programmes implemented by the United Nations. In 1969, Correia was contacted by the German UN officer and radical scholar Ernest Feder (1913-1984), who was managing the UN Development Programme in Ceylon and the Maldives at that time. Feder asked the Brazilian geographer if he was interested in "working in Ceylon with our agrarian research and training institute'. Feder stated, 'Your experience in the Northeast of Brazil and your recent work with SUDENE would prove to be valuable', offering an initial 2-year contract. ${ }^{21}$ Feder had also met de Andrade in Chile previously when he was a CEPAL (Comisión Económica para América Latina y el Caribe) ${ }^{22}$ officer in Mexico and had been assigned to manage 'a New Agrarian research and Training Institute in Ceylon with the FAO. The institute should be entirely similar to the one now existing in Santiago, which you know. The Institute does not exist yet. However, I expect that the contract between FAO and the Ceylonese government will be signed soon and that we shall begin to undertake research and train the Ceylonese at various levels of competency. It is my intention to secure staff of the highest level because the Institute is the first of its type and scope in South East Asia, and it is necessary to obtain the assistance of highly competent professionals. ... I would be pleased to work with you on the land tenure and agrarian problems of Ceylon. ${ }^{23}$ According to Eric Ross, Feder was another unorthodox and disaffected scholar committed to early critiques to development, while his book, Perverse Development, was 'one of the truly great critiques of the Green Revolution' (Ross, 2011, p. 343) and of the idea of modernization because the mere expansion of commercial farming and grazing 'only meant the further marginalization of the peasantry' (Ross, 2011, p. 341). Thus, these debates anticipated later critiques not only of neo-colonialism, but of the idea of

\footnotetext{
${ }^{21}$ IEB-MCA Caixa 36, Feder to de Andrade, 12 October 1969.

${ }^{22}$ This was a special UN agency for Latin America and a centre for debates on growth poles and dependency theory (Kay, 1989).

${ }^{23}$ IEB-MCA Caixa 41, Feder to de Andrade, 11 September 1969.
}

'Geographies of internationalism: radical development and critical geopolitics from the Northeast of Brazil', Political Geography, 63, 2018 10-19, https://www.sciencedirect.com/science/article/pii/Sog62629817302597 
development, addressed by a rich literature in the following decades (Power, 2003; Sidaway, 2007; Simon, 2007).

De Andrade's response shows that he agreed 'to accept the post on planning and agricultural politics of the Institute of Agrarian Research in Ceylon if the FAO offers me favourable work conditions'. ${ }^{24}$ This was a radical decision because de Andrade was unlikely to recover his chair in Recife after spending two years abroad. However, the project failed because Feder had to leave Ceylon due to disagreements with the local government in $1970^{25}$ and then joined the FAO office in Santiago. Again, he sought a position for Correia: 'I have suggested your name to Solon Barraclough ${ }^{26}$ as the best candidate for a post as project manager of the new Peruvian land reform institute ... which may be financed by the United Nations and implemented by the FAO. I hope that something will come of it. ${ }^{27}$ The sources do not reveal the outcomes of this proposals, but what is clear is that de Andrade was looking for new professional opportunities and found the UN agencies attractive. Nevertheless, the relationship with international agencies proved to be often negative for these critical geographers. For de Andrade, this was also the case with a UNESCO project for an international university. As mentioned above, de Andrade travelled in 1969 for a meeting on these topics and received correspondence from the organizing committee in the following years ${ }^{28}$ and wrote to learn more about this project. ${ }^{29}$ In 1974, he was told that the Chart of the United Nations University voted to target the ambitious goals of the 'autonomy, freedom and means to resolve the great and urgent problems of the world'30 and urged him to send suggestions and news on the 'Reaction in Brazil on this university' $^{31}$. We do not have further documents on this project's outcomes: during the dictatorship, de Andrade, was unlikely to become a 'Brazilian ambassador' for any international agency, as de Castro was prior to his exile.

\footnotetext{
${ }^{24}$ IEB-MCA, Caixa 41, de Andrade to Feder [1969].

${ }^{25}$ IEB-MCA, Caixa 41, Feder to de Andrade, [1970].

${ }^{26}$ Barraclough (1922-2002) was another radical scholar who was interested in agrarian reforms in Latin America.

${ }^{27}$ IEB-MCA, Caixa 41, Feder to de Andrade, 7 December 1970.

${ }^{28}$ IEB-MCA, Caixa 37, 11 June 1971, Projet de création d'une université internationale.

${ }^{29}$ IEB-MCA, Caixa 38, de Andrade to Cepede, 25 January 1973.

${ }^{30}$ IEB-MCA, Caixa 38, Sulli to de Andrade, 11 January 1974.

${ }^{31}$ IEB-MCA, Caixa 38, Sulli to de Andrade, 7 March 1974.
}

'Geographies of internationalism: radical development and critical geopolitics from the Northeast of Brazil', Political Geography, 63, 2018 10-19, https://www.sciencedirect.com/science/article/pii/Sog62629817302597 
Another correspondence that revealed Correia's willingness to find professional alternatives abroad concerned an incident about a planned visiting fellowship to which he was appointed at the University of Rennes, but the Brazilian geographer could not undertake the fellowship because his institution refused him permission to go. Sources reveal that the initiative came from de Andrade who, in a 1969 letter, acknowledged Philipponneau for 'the support you gave to my project for going to France as an associate professor ... I will need two or three months to obtain the permission from my university to leave the country'. ${ }^{32}$ It is worth noting that even today, Brazilian public servants, including academics, need to submit a pedido de afastamento (request for permission to travel) every time they materially cross the borders of the state where they are appointed. On the French side, matters appeared to proceed smoothly; Philipponneau responded to de Andrade that he had 'favourable advice from the Ministry of the Foreign Affairs, the Geography Institute and the Faculty of Arts ... your curriculum was well done and made a huge impression in Rennes.' 33 This appointment was for 'one year, more likely two ... with modules on Latin America and on the problems of tropical countries. ${ }^{34}$ Since then, a long correspondence states the problems Andrade encountered with his institution, first due to the academic calendar ${ }^{35}$ and then for more substantial issues. A disappointed Philipponneau lamented de Andrade's inability to reach Rennes in February 1971, despite the fact that the Brazilian academic year ended in December $1970 .{ }^{36}$ De Andrade apologized, stating that the 'Federal University of Pernambuco refused me permission to travel abroad as an Associate Professor ... under the allegation that there are no colleagues to take my place ... I truly apologize for all the inconvenience I am causing, but for me it is impossible to go to Rennes without the permission of my institution.' 37

In these circumstances, de Andrade looked similar to a prisoner: the technical reasons alleged by his university were clearly a pretext, and the fact that he sought positions outside Brazil suggests that he seriously considered definitive migration. A letter sent by Milton Santos, who by then had been in France for 6 years struggling to obtain a senior academic appointment

\footnotetext{
${ }^{32}$ IEB-MCA Caixa 41, de Andrade to Philipponneau, 21 September 1969.

${ }^{33}$ IEB-MCA Caixa 36, Philipponneau to de Andrade, 16 December 1969.

${ }^{34}$ IEB-MCA Caixa 41, Philipponneau to de Andrade, 5 June 1970.

${ }^{35}$ IEB-MCA Caixa 41, de Andrade to Philipponneau, 21 June 1970.

${ }^{36}$ IEB-MCA Caixa 41, Philipponneau to de Andrade 23 October 1970, 20 January 1971.

${ }^{37}$ IEB-MCA Caixa 41, de Andrade to Philipponneau 27 January 1971.
}

'Geographies of internationalism: radical development and critical geopolitics from the Northeast of Brazil', Political Geography, 63, 2018 10-19, https://www.sciencedirect.com/science/article/pii/Sog62629817302597 
there, reinforces this feeling. Santos appears to kindly reproach de Andrade's lack of courage in making his decision. 'What is amazing is that the posts for associate professor are rarer and rarer. You were nominated, appointed and you do not come ... You need to explain the Brazilian situation to the Rennes people to prevent any hard feelings and to perhaps receive another opportunity later.' ${ }^{38}$ De Andrade's choice to remain in Pernambuco was also due to his family situation (four children) and the difficulty of the conditions that other Brazilian dissidents experienced abroad. This bears witness to the importance of materiality and concrete conditions in explaining the production of knowledge, its localizations and its circulations (Livingstone, 2005; Naylor, 2005).

Forms of internationalization that appeared to work relatively better for de Andrade were university cooperation at a distance and work in the context of international scholarly organizations such as the IGU. The 'Big Man' of French scientific cooperation with Brazil and Latin America at that time was Pierre Monbeig (Clout, 2013), who had been acquainted with Correia since the years preceding the dictatorship. Monbeig travelled to Recife in September 1963, expressing interest in the 'situation in the Northeast, the plans for development, the activities of the SUDENE ... This documentation will be of great utility for the library and the economic seminaries of the Institute of Latin American Studies of the Paris University. ${ }^{39}$ This institute, the IHEAL (Institut des Hautes Etudes sur l'Amérique Latine), was a creation of Monbeig, which saw the collaboration of de Castro, de Andrade and Santos at different levels. In 1966, Monbeig told de Andrade of the foundation of the new institute. 'From November $1^{\text {st }}$ 1966, the IHEAL will develop its research activities ... As you can see, our concern is to give an interdisciplinary character to research. The problems of development in the Americas are not strictly economic or strictly sociological: they belong to both disciplines and it is worth replacing them in their geographical space and in their historical context.... We would be happy to receive those among your collaborators whom you might consider useful to join us for a French academic year' ${ }^{40}$. In 1972, Monbeig proposed collaboration to de Andrade in a task for which he was commissioned by the French government. 'It is a publication of a French

\footnotetext{
${ }^{38}$ IEB-MCA Caixa 41, Santos to de Andrade, 4 February 1971.

${ }^{39}$ IEB-MCA, Caixa 36, Monbeig to de Andrade, 27 August 1963.

${ }^{40}$ IEB-MCA, Caixa 35, Monbeig to de Andrade, 4 April 1966.
}

'Geographies of internationalism: radical development and critical geopolitics from the Northeast of Brazil', Political Geography, 63, 2018 10-19, https://www.sciencedirect.com/science/article/pii/Sog62629817302597 
governmental service called La documentation française ... one or two numbers on Brazil. ${ }^{41}$ Thus, Brazilian scholarship was involved in a dialogue for founding the IHEAL and still plays a key role in scientific cooperation with France. ${ }^{42}$

The second case of French-Brazilian cooperation involving de Andrade in Recife reveals the role of global player represented by Santos, then in Toulouse, who put de Andrade in contact with Bernard Kayser. 'Our friend Kayser will be in Brazil for a month ... I proposed that he stops in Recife for few days ... First, to give him the opportunity of experiencing Pernambuco's hospitality and working with you. Second, to allow him to discuss a project with you that we have on the Northeast, for which we would like to have your participation. ${ }^{43}$ Correia was at that time the facilitator of a programme by the French CNRS in his region, which aimed to conduct a major regional survey on development perspectives. Two years later, Kayser's letter stated that: 'The research we undertook with the support of the CNRS is now proceeding in all parts of Recife. I would be happy if you could include the region of Paraiba. To help you, during my last visit at the University of João Pessoa, I selected two advanced students who might be of help to you. ${ }^{44}$ The following year, Kayser, acknowledging the safe reception of de Andrade's report, wrote that he would have revised it with the help of Santos. ${ }^{45}$ Nevertheless, the experience of the dictatorship and what I would call De Andrade's 'internal exile' was difficult, though less harsh than Santos's experience, as witnessed by the messages the Bahia geographer periodically sent to de Andrade, confirming Edward Said's reflections on the fact that exile's 'essential sadness can never be surmounted' (Said, 2000, 173). 'You lived here, so you know that sending news [to Brazil] is more difficult than requesting it ... I work a lot; this is a way to fill my time and to alleviate my sorrow' ${ }^{46}$.

De Andrade also opened pathways of collaboration with the University of California, Riverside through his friend Ronald Chilcote, a specialist in Latin American issues who wrote to de Andrade in Portuguese and was especially interested in his work on 'The Cabanos war and

${ }^{41}$ IEB-MCA, Caixa 41, Monbeig to de Andrade, 8 May 1972.

${ }^{42}$ See the French-Brazilian geography journals Confins and Terra Brasilis.

${ }^{43}$ IEB-MCA Caixa 35, Santos to de Andrade, 30 May 1966.

${ }^{44}$ IEB-MCA, Caixa 37, Kayser to de Andrade, 15 December 1968.

${ }^{45}$ IEB-MCA, Caixa 37, Kayser to de Andrade, 17 September 1969.

${ }^{46}$ IEB-MCA, Caixa 35, Santos to de Andrade, 4 May 1966.

'Geographies of internationalism: radical development and critical geopolitics from the Northeast of Brazil', Political Geography, 63, 2018 10-19, https://www.sciencedirect.com/science/article/pii/Sog62629817302597 
Black revolts in Pernambuco' ${ }^{47}$. The importance of this book was in anticipating topics of present-day subaltern histories and subaltern spaces (Clayton 2011) and was one of the first examinations of the early revolts of peasants, indigenous people and caboclos beyond the classical Marxist accusation of these experiences being 'primitive', 'archaic' and 'antimodern'. According to de Andrade, these revolts, which occurred in the Northeast throughout the nineteenth century, had been 'taken superficially' (De Andrade, 1965, p. 14) by Brazilian historiography, which erected a 'silence curtain' to what were, on the contrary, the true 'mass revolutions, the popular ones' (De Andrade, 1965, 200), whose revolutionary leadership 'was constituted in great part by Jacuipe Indios and black slaves' (De Andrade, 1965, p. 204). This also anticipated current topics of the Modernity-Coloniality-Decoloniality movement on internal colonialism, coloniality of power and geopolitics of knowledge (Porto-Gonçalves and Araújo-Quental, 2012). Chilcote likewise travelled to Recife ${ }^{48}$ and was one of the facilitators for the English translation of de Andrade's most famous book, O Homem e a Terra no Nordeste (1969), by Dennis Johnson. ${ }^{49}$

Finally, Correa was the reference in Brazil for early Latin American radical geographies, as shown by his exchanges with the Argentinian geographer Carlos Reboratti, who was also Santos's correspondent. Reboratti was among the movers in a network of radical geographers that already involved hundreds of participants in the two Latin-American Encounters of Geography held in Argentina and Uruguay and was keen to involve Brazilian scholars. To explain the project to de Andrade, Reboratti wrote, 'Since the end of 1972, a group of geographers, students and teachers from Argentina and Uruguay started to have discussions from the perspective of a radical renovation of Latin American geography. Until now, this academic discipline oscillated between the old descriptive characteristics of positivist geographies and the new quantitative methods of the Anglo-Saxon school, which are so difficult to apply in a specific environment like ours.... Our aim is to adapt geographical methods and theories to the Latin American situation, ... that is radically different from those where the existing theories were developed'.$^{50}$ If a central issue was 'underdevelopment', it is

\footnotetext{
${ }^{47}$ IEB-MCA, Caixa 36, Chilcote to de Andrade, 20 August 1967.

${ }^{48}$ IEB-MCA, Caixa 34, Chilcote to de Andrade, 21 June 1969.

${ }^{49}$ IEB-MCA, Caixa 40, Johnson to de Andrade, 6 December 1976.

${ }^{50}$ IEB-MCA, Caixa 38, Reboratti to de Andrade, 11 April 1974.
}

'Geographies of internationalism: radical development and critical geopolitics from the Northeast of Brazil', Political Geography, 63, 2018 10-19, https://www.sciencedirect.com/science/article/pii/Sog62629817302597 
worth noting that this problematization anticipated present-day decolonial claims for the epistemological specificity of Latin American 'geopolitics of knowledge' (Mignolo, 2002).

Reboratti's letters included a chronicle of the first two meetings of the Nueva Geografia. 'The first one occurred in Salto (Uruguay) in February 1973 with the participation of approximately 80 people. The success of this meeting, and the feelings it stimulated, allowed for a second meeting in Neuquen (Argentina) in February 1974, where the number of attendees reached 250 and were mainly from Argentina and Uruguay (and Milton Santos as the sole delegate from Brazil). From this meeting, we succeeded in creating a definitive organization in the Latin American Geography meetings, with the creation of local centres in Neuquen, Buenos Aires, Mendoza, Montevideo, Uruguay Interior, Tucuman and Bahia Blanca.'51 According to Reboratti, 'our task is long and difficult: the old geography still exists, and its strongest representatives ... are unwilling to let the new ideas through. In Argentina, this is not only an academic position, as this entails important economic (especially editorial) interests. However, we count on the encouraging enthusiasm of most of the new geographers' generations' ${ }^{52}$ This correspondence shows the importance of de Andrade in continental networking but also the significance of political contexts and material constraints in the study of scientific movements: recent Argentinian scholarship has shown that these meetings played a seminal role for later developments of critical geography in the region, but the project was materially interrupted by the action of the dictatorships in Argentina and Uruguay (Quintero, Dufour and Iut, 2009).

De Andrade's cosmopolitan views are seen in some statements: 'Let us consider that science cannot be included in a unique state or country because it implies the concurrency of wider principles, which are never restricted to a unique region' (De Andrade, 2007, p. 9). Nevertheless, his radical ideas never prevented him from participating in institutional projects during the dictatorship, such as 'a programme for populating the rainforest by the State of Pernambuco ... and a task force on agrarian reform to advise the Federal Government' in $1968^{53}$. Towards the end of the 1970s, when the dictatorship became more 'accommodating' and Brazilian geography had a 'critical turn' with the return of Milton Santos and the 1978

\footnotetext{
${ }^{51}$ IEB-MCA, Caixa 38, Reboratti to de Andrade, 11 April 1974.

52 IEB-MCA, Caixa 38, Reboratti to de Andrade, 28 May 1974.

${ }^{53}$ IEB-MCA, Caixa 33, de Andrade to Levy, 15 November 1968.
}

'Geographies of internationalism: radical development and critical geopolitics from the Northeast of Brazil', Political Geography, 63, 2018 10-19, https://www.sciencedirect.com/science/article/pii/Sog62629817302597 
Congress of Fortaleza (Buss et al., 1991), de Andrade continued his international networking and was apparently less active in attempts to leave the country. At the end of 1977, he was invited for a month by Michel Rochefort, Santos's former supervisor in Strasbourg, to give talks in France. ${ }^{54}$

This section has shown the importance of international networking in cases of political constraints and the uses of international hospitality to overcome isolation and political marginalization, which was even more urgent in a region that was in the 'extreme periphery' of international scholarship. The Brazilian Northeast came to play a protagonist role in development debates thanks to the volunteer networking of its geographers, which can be fully revealed only by a network analysis based on primary sources.

\section{Milton Santos and the difficult 'Global North'}

Complementing recent studies reviving Santos's work in international scholarship (Ferretti and Viotto, 2017; Grimm, 2011; Melgaço and Prouse, 2017), this section especially focuses on his exile in France (1964-1971) to show both the hindrances that state and academic institutions can involve for an international scientific life and the indirect stimulations that power can provide by compelling scholars to travel. Santos came from the State of Bahia, and from his youth, he had been acquainted with Pernambuco scholars such as de Castro (as documented above) and de Andrade. A 1960 letter from Santos to de Andrade alludes to the organization of a shared symposium at the University of Bahia and to "common friends'55. The correspondence between Santos and de Andrade is the first important indicator of the role the former played as a pivotal figure for networking since the beginning of his exile but also of the material difficulties that this work encountered.

On the one hand, Santos involved de Andrade in initiatives such as a seminar on the 'Regionalization of Space in Brazil' he organized with Guy Lasserre at the Centre for Tropical Studies at the University of Bordeaux. ${ }^{56}$ On the other hand, Santos related confidentially the feelings of someone who is rejected both by his homeland and by (conservative) international

\footnotetext{
${ }^{54}$ IEB-MCA, Caixa 40, Rochefort to de Andrade, 17 August 1977.

${ }^{55}$ IEB-MCA, Caixa 35, Santos to de Andrade, 11 March 1960.

${ }^{56}$ IEB-MCA, Caixa 34, Lasserre to Santos, 4 September 1968.
}

'Geographies of internationalism: radical development and critical geopolitics from the Northeast of Brazil', Political Geography, 63, 2018 10-19, https://www.sciencedirect.com/science/article/pii/Sog62629817302597 
institutions. 'In Brazil, I do not have valid intermediaries to place my manuscripts. It is like I had lost a part of my own country ... I was ejected from the United Nations, and I am now permanently in Paris. ${ }^{57}$. In his recollections, Santos explained that this 'ejection' was due to his intellectual independence. 'In 1968, I started collaboration in Venezuela, where I was appointed director of a United Nations programme for the study and planning of Venezuelan urbanization. I could not remain there because I wanted to apply the theories on which I was working, and the UN heads wanted me to apply theories in which I did not believe. A conflict arose, and as I still had a position at the Sorbonne, I preferred to return there' (Buss et al., 1991, p. 191). This confirms what the aforementioned works on the United Nations argue about the contradictions of the international institutions: because many radical development and decolonization scholars trusted in international agencies as possible progressive allies, they were generally deceived by the fact that international organizations always remained dependent on major powers and international capital (De Andrade et al., 2003).

Santos later received new appointments from the Venezuela government in 1970 to perform 'the integral study of the River Chama basin in the Andes region... This is a work of applied geography for the Andes Development Corporation for one year.' ${ }^{58}$ This could also imply a renewable appointment for Santos at the local Universidad de los Andes. In his recollections, Santos stated that 'the Venezuelans adopted me' (Buss et al., 1991, p. 192), confirming Mario Sznajder's and Luis Roniger's remarks on how "Venezuela emerged as a pole of attraction for exiles after is democratization in 1958" (Sznajder and Roniger, 2007, p. 23). Nevertheless, his archives show that the reception of Santos's work there was also varied: he was appreciated by critical academics and scholars who were acquainted with him, but the government remained doubtful, entrusting him with a geographical study of the Vargas department (Northern Venezuela) without giving him the necessary means, which Santos complained about in his letters. ${ }^{59}$ Santos was then informed that the President of the Congress had decided to 'unilaterally rescind' 60 their contractual relationship. However, Santos continued to collaborate with Venezuelan universities in the following years (Santos, 2001).

\footnotetext{
${ }^{57}$ IEB-MCA, Caixa 34, Santos to de Andrade, 16 July 1969.

${ }^{58}$ IEB, Milton Santos archives, Unrecorded Items (hereafter MS), Caixa 34/37, Vivas to Santos, 12 March 1970.

${ }^{59}$ IEB, MS, Caixa 31/37, Santos to Fermin; 7 August 1970.

${ }^{60}$ IEB, MS, Caixa 34/37, Rivera Oviedo to Santos, 13 August 1970
}

'Geographies of internationalism: radical development and critical geopolitics from the Northeast of Brazil', Political Geography, 63, 2018 10-19, https://www.sciencedirect.com/science/article/pii/Sog62629817302597 
During these years, the most revealing story is doubtlessly Santos's eviction from the Paris Institut d'étude du développement économique et social (IEDES), where he was the director of the research cluster Regional and Territorial Planning. After enduring the Brazilian dictatorship, Santos was confronted with the centralism and authoritarianism of the French Cinquième République. There, the directors of research institutes such as the IEDES were nominated by the government on political rather than scientific bases. Thus, the appointment of Jean-Jacques Juglas (1904-1978), former minister and deputy for the Catholic party Mouvement républican populaire, corresponded to a governmental willingness to normalize development studies in France, of which Santos was the first victim. The newly installed director first bullied the Brazilian geographer with sarcastic messages complaining about Santos's nonattendance at an administrative meeting ${ }^{61}$ and then directly dismissed him. A public statement of the researchers' assembly denounced this abuse. 'The Research Department is threatened by increasingly authoritarian and arbitrary measures targeting a reorganization that questions the integrity of the existing groups and thus the security of the researchers' employment. ${ }^{, 62}$ A major concern was the fact that the thirty researchers appointed to the IEDES were all non-tenured, including the groups' directors. The researchers especially criticized the creation of a parallel institute, the Fondation universitaire du développement économique et social, which was likewise chaired by Juglas in an open conflict of interest, fearing that it was a way to liquidate the IEDES by 'replacing [our] groups and determining their dismissal'. ${ }^{63}$

The document denounced Santos's dismissal. 'Professor Milton Santos was compelled to resign from his role as the Director of the taught programme of Regional Analysis and Spatial Planning. Without any other reasons than this demission and abuse of his cumulating functions as director of the institute and of research, Mr. Juglas immediately notified the interested person, 'I do not think it is possible for you to continue in other activities within the Institute' ${ }^{64}$ The researchers announced their intention to "struggle with all the means we consider suitable [and] to denounce the fact that Mr. Juglas dared to dismiss Professor Santos as director of the

\footnotetext{
${ }^{61}$ IEB, MS, Caixa 34/37, Julgas to Santos, 22 April 1970.

${ }^{62}$ IEB, MS, Caixa 31/37, Communiqué, 11 March 1971.

${ }^{63}$ IEB, MS, Caixa 31/37, Communiqué, 11 March 1971.

${ }^{64}$ IEB, MS, Caixa 31/37, Communiqué, 11 March 1971.
}

'Geographies of internationalism: radical development and critical geopolitics from the Northeast of Brazil', Political Geography, 63, 2018 10-19, https://www.sciencedirect.com/science/article/pii/Sog62629817302597 
group without any reason'. ${ }^{65}$ For reasons that were independent of this protest, Juglas was replaced the following year. Santos's friend and confident at IEDES, Georges Coutsinas, sent sarcastic notes on the succession to the Brazilian geographer: 'We have two candidates, one from Paris 1. [He is] Mr. Pierre Dabezies, a former paratrooper colonel, who, after quitting the Army, earned a Master of Law degree and now teaches the state and the army. As you see, he does not know anything about underdevelopment (although he had direct contact with it wars in Indochina and Algeria), he has no vision about what IEDES missions and functions should be, and his only arguments are his friendship with some ministers and high functionaries. The other candidate ... is Professor René Dumont, who does not need presentations. ${ }^{66}$ Will the Minister appoint him without excessive problems or will it be necessary to fight again, and with what results?' ${ }^{97}$

Meanwhile, Santos had already been established in the USA for his year at MIT at the beginning of a decade where he was one of the protagonists in the rise of radical geographies in collaboration with Richard Peet and the Antipode circuit (Ferretti and Viotto, 2017). What is relevant for my argument here is that this case shows that institutional constraints can play a double role in the production of knowledge and its international circulation. They might entail hindrances, as seen when Santos's work in France was brutally interrupted, but they also create (indirect) opportunities. As Santos explained in a 1971 letter to de Andrade, his sojourn at MIT was instrumental in building the theory of the Shared Space (Santos 1979). 'My task here is to write a book on the two circuits of urban economy in underdeveloped countries and its spatial repercussions. I think it will be an important contribution to the study of space in underdeveloped countries ... I came here precisely to complement my French documentation with Anglo-Saxon material and to have all the rest of the time to reflect and write' ${ }^{68}$ This spectacularly international and transcultural career was highlighted by Lasserre, who wrote to Santos, 'I admire you because you are Brazilian; you assimilated into the French culture and speak the language perfectly, and now you are doing the same with English and the American

\footnotetext{
${ }^{65}$ IEB, MS, Caixa 31/37, Communiqué, 11 March 1971.

${ }^{66}$ René Dumont (1904-2001), French agronomist interested in peasants' struggles in the South, was considered the only competent candidate by the correspondents.

${ }^{67}$ IEB, MS, Caixa 31-37, Coutsinas to Santos, 9 February 1972.

${ }^{68}$ IEB-MCA, Caixa 37, Santos to de Andrade, 23 October 1971.
}

'Geographies of internationalism: radical development and critical geopolitics from the Northeast of Brazil', Political Geography, 63, 2018 10-19, https://www.sciencedirect.com/science/article/pii/Sog62629817302597 
culture. I would not be able to do the same'. ${ }^{69}$ Therefore, exile can play a creative role for international, transnational and cosmopolite geographies.

\section{Conclusion}

This article has shown the importance of rooting internationalism in its places, institutional and non-institutional, and in its motivations. Voluntarism, activism, multilingualism and political radicalism constituted a strong drive towards the creation of non-institutional spaces, networks and circuits for international and transnational scholarly work. A very important part of these processes can be considered the circulation of knowledge, including translation (as in the case of all the Brazilian scholars addressed here) and editorial practices like de Andrade's importation of international books and journals in Pernambuco. The difficulties of these exchanges were material and economic ones, but belonged especially to political repression and to limitations involved by the constructions of national and nationalistic scholarly frameworks. This results especially clear if one considers Santos's experience in France.

On the other side, also concrete places played a role in shaping internationalism, as in the case of Brazil's Northeast (Ferretti, 2018). It is worth noting the importance of the South-South exchanges performed by these exiled, for instance Santos's work in Africa (Santos, 2001) and de Andrade's Latin American correspondence mentioned above. As recent work suggested (Melgaço and Prouse, 2017; Ferretti and Viotto, 2017), these Brazilian geographers support the case for the rediscovery of authors from the global South in international debates on critical geographies and development studies since the 1960. For de Castro, his role as the inspiration for the other two is clear, while the impact of his work on social geographies and critical geopolitics in the 'North' will be the object of further work on his archives in Recife. In the case of de Andrade, his role in promoting the Northeast as a 'problem region' (De Andrade, 1969) paralleled de Castro's humanitarian claims and contributed, as this material shows, to calling the attention of European observers to the problems of this region. However, they also called for a rehabilitation of local indigenous and black histories, as demonstrated by their works and correspondences mentioned above, and participated in a more general movement

\footnotetext{
${ }^{69}$ IEB, MS, Caixa 34/37, Lasserre to Santos, 3 February 1972.
}

'Geographies of internationalism: radical development and critical geopolitics from the Northeast of Brazil', Political Geography, 63, 2018 10-19, https://www.sciencedirect.com/science/article/pii/Sog62629817302597 
'from the South' dealing with a radical idea of development intended not as the continuation of colonialism, but as its definitive end.

The role of Santos as a global player for critical scholarship is confirmed here, but these new archives suggest that this role was paradoxically due to difficult material conditions and hindrances. In all these cases, the study of the material conditions of 'internal' or 'external' exile shows that, on the one hand, political persecution limits the production and circulation of knowledge. On the other hand, exile can also play a 'creative' role. In the case of Santos, for instance, it was his eviction from Brazil that pushed him to play a leading role in French development geography, and then it was his eviction from the Paris IEDES that pushed him to do the same in Anglo-American radical geographies (see also Power and Sidaway, 2004).

On the other hand, this demonstrates the importance of following both institutional and noninstitutional as well as formal and informal networks of sociability to open 'Pandora's black box of science' (Latour, 1987, p. 2) and to appreciate the internationalization of scholarly exchanges within a scientific movement. In the case of de Andrade, the international correspondence of the 1960s-70s was clearly used as a device to avoid political and academic marginalization and allow a better understanding of the statement by Hodder, Legg and Heffernan that internationalism is rooted in strong aspirational bases and in a belief that internationalism offered a crucial (and often sole) route to a more peaceful, progressive or prosperous future' (Hodder, Legg and Heffernan, 2015 p. 4). However, the contradictions of these concepts, highlighted by these authors, are confirmed by the difficulties the Brazilian exiled geographers experienced with the different UN agencies with which they collaborated. Thus, scholarly life is not straightforwardly international; it requires volunteer effort, which can be rooted in political commitment but for which political and 'radical' commitment does not always suffice. An exemplar anecdote is included in the correspondence between Santos and the Argentinian radical geographic association Espacio Libre (Free Space), whose representative Néstor Miguel Gorojovski asked the Brazilian to help them contact the Italian Marxist geographer Massimo Quaini. 'We sent him numerous letters, but the man is perhaps too haughty' ${ }^{70}$. This is an example that these Brazilian networks can provide insights even

${ }^{70}$ IEB, MS-RS85-077, Gorojovsky to Santos, 3 October 1985.

'Geographies of internationalism: radical development and critical geopolitics from the Northeast of Brazil', Political Geography, 63, 2018 10-19, https://www.sciencedirect.com/science/article/pii/Sog62629817302597 
today to 'decolonize' the scholarly relations between the North and South and discard the lasting pretentions of 'scientific' superiority.

\section{References}

Agulhon, M. (1966). La sociabilité méridionale, Confréries et associations dans la vie collective en Provence orientale la fin du XVIIIe siècle. Aix-en-Provence: La pensée universitaire.

Borzacchiello da Silva, J. (2016) French-Brazilian geography: the influence of French geography in Brazil. Berlin: Springer.

Bué, A. (2009). Josué De Castro, un visionnaire brésilien à Vincennes. In J.-M. Djian, (Ed.), Vincennes, une aventure de la pensée critique (pp. 126-129). Paris : Flammarion.

Buss, M.D., Mamigonian, A., Machado, V.V. and Pereira M.F. (1991), Entrevista com o professor Milton Santos. Geosul 6, 170-201.

Carvalheira do Nascimento, R (2009). O resgate da obra de Josué de Castro, onde estamos?, Cronos, 10, 43-50.

Clayton, D. (2011). Subaltern space. In J. Agnew \& D. Livingstone (Eds.). The SAGE handbook of geographical knowledge (pp. 246-261). London: SAGE.

Clout, H. (2013). Pierre Monbeig (1908-1987). In Lorimer, H. \& Withers CJ.W. (Eds.). Geographers, Biobibliographical Studies, vol. 32 (pp. 54-78). London: Bloomsbury.

Contel, F. (2014). Milton Santos. In L. Secco \& L.B. Pericas (Eds.). Intérpretes do Brasil (393409). São Paulo: Boitempo.

Craggs, R. (2014). Hospitality in geopolitics and the making of Commonwealth international relations. Geoforum, 52, 90-100.

Craggs, R. \& Mahony, M., The Geographies of the Conference: Knowledge, Performance and Protest. Geography Compass, 8(6), 414-430.

Davis, M (2001). Late Victorian Holocausts: El Niño famines and the making of the Third World. London, Verso.

De Andrade M.C. (1965). A Guerra dos cabanos. Rio de Janeiro: Conquista.

De Andrade M.C. (1969). A terra e o homem no Nordeste. São Paulo: Editora Brasiliense.

'Geographies of internationalism: radical development and critical geopolitics from the Northeast of Brazil', Political Geography, 63, 2018 10-19, https://www.sciencedirect.com/science/article/pii/Sog62629817302597 
De Andrade, M.C., Da Silva, J.G., Belik W. Takagi M., Costa, H., Batista, M.F., Batista, L.V., De Melo D.A.F., Soares, J.A., Santana, P., Duarte, R. \& Zaidan M.F. (2003). Josué de Castro e o Brasil. São Paulo: Editora Fundação Perseu Abramo.

De Castro, J. (1946). A Geografia da Fome. Rio de Janeiro, O Cruzeiro.

De Castro, J. (1952). Géopolitique de la faim. Paris, Les éditions ouvrières.

Domosh, M. (2015). International Harvester, the U.S. South, and the makings of international development in the early 20th century. Political Geography, 49, 17-29.

Edwards, B.H. (2003). The practice of diaspora: literature, translation, and the rise of Black internationalism. Cambridge, Harvard University Press.

Espagne, M. (2013). La notion de transfert culturel. Revue Sciences/Lettres http://rsl.revues.org/219

Featherstone D. (2013). Black Internationalism, subaltern cosmopolitanism, and the spatial politics of antifascism. Annals of the Association of American Geographers, 103, 1406-1420.

Featherstone, D. (2012). Solidarity: hidden histories and geographies of internationalism.

London: Zed.

Ferretti, F. (2011). The correspondence between Élisée Reclus and Pëtr Kropotkin as a source for the history of geography, Journal of Historical Geography, 37, 216-222

Ferretti, F (2018) Radicals from the Northeast: geographies of hunger and socio-natural hybridity in the works of Josué De Castro and Manuel Correia de Andrade. Antipode [under review].

Ferretti, F. \& Viotto, B. (2017). Inventing critical development: a Brazilian geographer and his Northern networks. Transactions of the Institute of the British Geographers [forthcoming].

Grimm Andrade, F. (2011). Trajetória epistemólogica de Milton Santos, uma leitura a partir da centralidade da técnica, dos diálogos com a economia política e da cidadania como práxis. São Paulo: PhD Dissertation.

Hepple, L. (2000). Yves Lacoste, Hérodote and French radical geopolitics. In K. Dodds \& D. Atkinson (Eds.). Geopolitical Traditions (pp. 268-301). London: Routledge.

Hodder, J. (2015). Conferencing the international at the World Pacifist Meeting, 1949. Political Geography 49, 40-50.

Hodder, J., Legg, S. \& Heffernan, M. (2015). Introduction: historical geographies of internationalism, 1900-1950. Political Geography 49, 1-6.

'Geographies of internationalism: radical development and critical geopolitics from the Northeast of Brazil', Political Geography, 63, 2018 10-19, https://www.sciencedirect.com/science/article/pii/Sog62629817302597 
Ince, A. \& Barrera de la Torre G. (2016). For Post-Statist Geographies. Political Geography, $55,10-19$.

Jöns H., Meusburger P. \& Heffernan M. (2017). Mobilities of Knowledge. Berlin: Springer.

Kay, C. (1989). Latin American theories of development and underdevelopment. London and New York: Routledge.

Keighren I., Crampton M., Ginn, F., Kirsch, S., Kobayashi, A. Naylor, S. \& Seemann, J. (2017). Teaching the history of geography: current challenges and future directions. Progress in Human Geography, 41, 245-262

Lacoste, Y. (1962), Le sous-développement. Annales de Géographie 71, 247-278.

Latour, B. (1987). Science in action: how to follow scientists and engineers through society. Cambridge: Harvard University Press.

Legg, S. (2010). Transnationalism and the scalar politics of imperialism. New Global Studies $4,1-17$.

Legg, S. (2014). An international anomaly? Sovereignty, the League of Nations, and India's princely geographies. Journal of Historical Geography 43, 96-110.

Leite Linhares, M.Y. (2007), Biografia. In Mançano Fernandes, B. \& Porto-Gonçalves, C.W. (2007). Josué de Castro, vida e obra (pp. 21-26). São Paulo, Expressão Popular

Livingstone, D. (2005). Science, text and space: thoughts on the geography of reading. Transactions of the Institute of British Geographers 30, 391-401.

Mamadouh, V. (1999). Reclaiming geopolitics: geographers strike back. Geopolitics 4,118138.

Mançano Fernandes, B. \& Porto-Gonçalves, C.W. (2007). Josué de Castro, vida e obra. São Paulo, Expressão Popular.

McGregor. J. (2017) Locating exile: decolonization, anti-imperial spaces and Zimbabwean students in Britain, 1965-1980. Journal of Historical Geography 57, 62-75.

Melgaço, L. (2017) Thinking outside the bubble of the Global North: introducing Milton Santos and 'the active role of geography' Antipode http://onlinelibrary.wiley.com/doi/10.1111/anti.12319/full DOI: 10.1111/anti.12319 [Early View].

Melgaço, L. \& Prouse C. (2017). Milton Santos: Pioneer in Geography. London: Springer.

'Geographies of internationalism: radical development and critical geopolitics from the Northeast of Brazil', Political Geography, 63, 2018 10-19, https://www.sciencedirect.com/science/article/pii/Sog62629817302597 
Mignolo W. (2002). The geopolitics of knowledge and the colonial difference. South Atlantic Quarterly 101, 57-96.

Nally, D. \& Taylor, S. (2015). The politics of self-help: the Rockefeller Foundation, philanthropy and the 'long' Green Revolution. Political Geography 49, 51-63.

Nally, D. (2016). Against Food Security: on Forms of care and fields of violence. Global Society 30, 558-582.

Naylor, S. (2005). Historical geography: knowledge, in place and on the move. Progress in Human Geography 29, 626-634.

Peet, R. \& Hartwick E. (2009). Theories of development. London: The Guilford Press.

Porto-Gonçalves, C.W. and Araújo Quental, P. (2012) Colonialidade do poder e os desafios da integração regional na América Latina. Polis 31 http://polis.revues.org/3749

Power M. (2003). Rethinking development geographies. London, Routledge.

Power, M. \& Sidaway J.D. (2004). The degeneration of tropical geography. Annals of the Association of American Geographers 94, 585-601.

Quintero, S., Dufour, E. \& Iut, V. (2009). Los Encuentros de la Nueva Geografía y el surgimiento de la geografía crítica en Uruguay y Argentina durante los años '70, http://observatoriogeograficoamericalatina.org.mx/egal12/Teoriaymetodo/Geografiahistorica ehistoriadelageografia/02.pdf

Robic, M.-C. (2013). À propos de transferts culturels. Les congrès internationaux de géographie et leurs spatialités. Revue germanique internationale 12, 33-45, http://rgi.revues.org/257

Ross, E.B. (2011). A critic unfettered: the legacy of Ernest Feder. Development and Change $42,330-348$.

Said, E. (2000) Reflections on exile and other literary and cultural essays London: Granta Books.

Santos, M. (1979) The shared space: the two circuits of the urban economy in underdeveloped countries London: Methuen.

$\begin{array}{llll}\text { Santos, } & \text { M. } & \text { (2001) } & \text { Curriculum }\end{array}$ http://www.miltonsantos.com.br/site/miltonsantos_curriculum.pdf.

Secord, J. (2004). Knowledge in transit. Isis 94, 654-672.

Sidaway, J. (2007). Spaces of Postdevelopment. Progress in Human Geography 31, 345-361.

'Geographies of internationalism: radical development and critical geopolitics from the Northeast of Brazil', Political Geography, 63, 2018 10-19, https://www.sciencedirect.com/science/article/pii/Sog62629817302597 
Simon, D. (2007). Beyond antidevelopment: discourses, convergences, practices. Singapore Journal of Tropical Geography 28, 205-218.

Slater, D. (1993). The geopolitical imagination and the enframing of development theory. Transactions of the Institute of British Geographers 18, 419-437.

Soares, J.A. (2003). Josué De Castro, o Brasil e o mundo. In De Andrade, M.C., et al. Josué de Castro e o Brasil (pp. 7-10). São Paulo: Editora Fundação Perseu Abramo.

Springer, S. (2016). The anarchist roots of geography. Minneapolis: Minnesota University Press.

Stepan, N. (2000). Tropical modernism: designing the tropical landscape. Singapore Journal of Tropical Geography 21, 76-91.

Sznajder, M., Roniger, L. 2007. Political Exile in Latin America. Latin American Perspectives 34, 4, 7-30.

Teles de Carvalho A. A. (2009). Josué de Castro e a inclusão da fome nos Estudos Geográficos do Brasil. São Paulo: PhD Dissertation.

Werner, M. \& Zimmermann B. (Eds.) (2004). De la comparaison à l'histoire croisée. Paris: Seuil.

Withers, C. (2007). History and philosophy of geography 2004-2005: biographies, practices, sites. Progress in Human Geography 31, 67-76.

'Geographies of internationalism: radical development and critical geopolitics from the Northeast of Brazil', Political Geography, 63, 2018 10-19, https://www.sciencedirect.com/science/article/pii/Sog62629817302597 